®O. В. Кравченко, С. В. Печеряга

Буковинський державний медичний університет

\title{
ОСОБЛИВОСТІ ФОРМУВАННЯ СУДИННОГО КОМПОНЕНТА ХОРІОНА ПРИ НЕВИНОШУВАННІ В І ТРИМЕСТРІ ГЕСТАЦІЇ
}

\begin{abstract}
ОСОБЛИВОСТІ ФОРМУВАННЯ СУДИННОГО КОМПОНЕНТА ХОРІОНА ПРИ НЕВИНОШУВАННІ В І ТРИМЕСТРІ ГЕСТАЦІї. Вивчені особливості формування судинного компонента хоріона за допомогою тривимірного ультразвукового дослідження у 30 пацієнток з невиношуванням та 30 вагітних з неускладненим перебігом гестації в І триместрі. Встановлено, що об'єм порожнини плідного яйця та об'єм хоріона були достовірно меншими при невиношуванні вагітності, індекс васкуляризації також був у 3 рази нижчим у даній групі, порівняно 3
\end{abstract} контролем.

ОСОБЕННОСТИ ФОРМИРОВАНИЯ СОСУДИСТОГО КОМПОНЕНТА ХОРИОНА ПРИ НЕВЫНАШИВАНИИ В । ТРИМЕСТРЕ ГЕСТАЦИИ. Изучены особенности формирования сосудистого компонента хориона с помощью трехмерного ультразвукового исследования у 30 пациенток с невынашиванием и 30 женщин с неосложненным течением беременности в I триместре. Установлено, что объем полости плодного яйца и объем хориона были достоверно меньшими при невынашивании беременности, индекс васкуляризации также был в 3 раза ниже в данной группе, в сравнении с контролем.

FEATURES OF FORMATION OF THE VASCULAR COMPONENT CHORIONIC FOR MISCARRIAGE IN THE I TRIMESTER OF GESTATION. Formation peculiarities of the vascular component of the chorion using three - dimensional ultrasound examination in 30 patients with miscarriage and in 30 women with uncomplicated pregnancy in the first trimester. It is established that the volume of the cavity of the ovum and the volume of villi were significantly lower for miscarriage, vascularization index was 3 times lower in this group compared with the control.

Ключові слова: судинний компонент хоріона, невиношування, I триместр гестації.

Ключевые слова: сосудистый компонент хориона, невынашивание, I триместр гестации.

Key words: chorionic vascular component, miscarriage, I trimester of gestation.

ВСТУП. Порушення функції плаценти сьогодні $€$ основною причиною перинатальної захворюваності і смертності. За даними ряду авторів, серед всіх ускладнень вагітності друге місце займає загроза невиношування, досягаючи $22 \%[3,4]$. Це ускладнення призводить до втрати вагітності чи народження незрілої дитини, яка потенціально має високий ризик розвитку захворювань.

Недостатність плаценти слід розглядати як зниження ії спроможності підтримувати адекватний обмін між організмами матері і плода. Становлення численних функцій плаценти тісно пов'язане з її структурою на різних етапах розвитку.

Адекватний перебіг періоду імплантації, органогенезу забезпечується, в першу чергу, випереджуючим ростом провізорних органів, зміною гістотрофічного типу живлення зародка спочатку на жовтковий, а згодом на гемохоріальний кровообіг [2]. Загроза переривання вагітності в I триместрі гестації несе в собі потенційну небезпеку порушень нормального розвитку екстраембріональних структур, процесів інвазіїтрофобласта, гестаційної перебудови спіральних артерій і формування плодово-плацентарного і матково-плацентарного кровообігу. Звідси стає зрозумілою необхідність вивчення особливостей формування судинного компонента хоріона при загрозі невиношування вагітності в I триместрі гестації [1].

Метою нашої роботи було оцінити морфофункціональний стан хоріона у жінок з загрозою переривання вагітності в I триместрі гестації.
МАТЕРІАЛИ ТА МЕТОДИ. Нами проведено проспективне обстеження 30 вагітних з загрозою переривання в терміні гестації 7-9 тижнів, які склали । групу, і 30 вагітних з неускладненим перебігом вагітності в тому ж гестаційному терміні (II група). Всім пацієнткам проводили повне клініко-лабораторне обстеження. При ультразвуковому дослідженні, окрім рутинного обстеження плода, вивчали об'єм плідного яйця і порожнини амніона, локалізацію ворсинчастого хоріона, а також додатково з використанням спеціальної тривимірної програми VOCAL проводили підрахунок об'єму хоріона $\left(\mathrm{V}_{\mathrm{x}}\right)$, оцінювали його судинну сітку на основі визначення індексу васкуляризації (VI) та індексу кровотоку (FI).

РЕЗУЛЬТАТИ ДОСЛІДЖЕННЯ ТАЇХ ОБГОВОРЕННЯ. Групи обстежених жінок були репрезентативні за віком, соціальним статусом і терміном вагітності. В

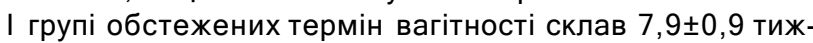

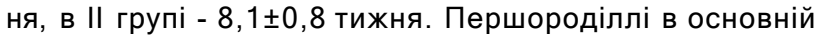
групі склали 70,0\%, в контролі - 66,7 \%, відповідно, повторнонароджуючих було 30 \% і 33,3 \%.

За даними акушерсько-гінекологічного анамнезу нами встановлено, що у жінок з загрозою переривання вагітності в анамнезі достовірно частіше зустрічались самовільні викидні $16,6 \pm 1,2 \%$ в порівнянні 3 контролем $3,3 \pm 0,9 \%(p<0,05)$. За кількістю штучних переривань вагітності, наявністю в анамнезі викидня, що не відбувся, позаматкової вагітності та оперативних втручань на жіночих статевих органах досліджені нами групи не відрізнялись. 


\section{Акушерство та гінекологія}

слід вІдмІтити, що вІд хронічних запальних процесів придатків матки, полікістозу яєчників, ерозії шийки матки, доброякісних пухлин матки ДО вагітності пацієнтки обох груп страждали однаково часто, тоды як аденоміоз у жінок основної групи В порівнянні 3 контролем діагностувався В 3 рази частіше $(36,6 \pm$ $3,2 \%$ । 3,3 $\pm 0,8 \%$ ).

ЩО стосується екстрагенітальної захворюваності, ТО В групі жінок з невиношуванням вона була діагностована у 18 випадках, що склало 60 \%, тоді як у жінок із фізіологічним перебігом вагітності тільки В 7 (23,3\%). На нашу думку, несприятливий екстрагенітальний фон сприяє порушенню нормального перебігу вагітності I є додатковим фактором ризику загрози невиношування.

3 даних, представлених у таблиці 1, видно, ЩО об'єми амніотичної порожнини у жінок досліджених груп достовірно не розрізнялись, але об'єм порожнини плідного яйця був достовірно меншим при загрозі невиношування вагітності В порівнянні 3 контрольною групою. В той же час співвідношення об'ємів порожнини хоріона й амніона В I групі обстежених було достовірно вищим у порівнянні зі здоровими

\section{Таблиця 1. Об'єм порожнин плідного яйця i амніона при загрозі невиношування в 7-9 тижнів гестації}

\begin{tabular}{|c|c|c|c|}
\hline $\begin{array}{c}\text { Групи } \\
\text { досліджених }\end{array}$ & $\begin{array}{c}\mathrm{V}_{\text {пя, }}, \mathrm{Mm}^{3} \\
\mathrm{M}+\mathrm{rn}\end{array}$ & $\begin{array}{c}\mathrm{V}_{\mathrm{An}}, \mathbf{M M}^{3} \\
\mathrm{M}+\mathrm{rn}\end{array}$ & $\begin{array}{c}\mathbf{V}^{\mathbf{T M}} / \mathbf{V}_{\mathbf{A n}} \\
\mathrm{M}+\mathrm{rn}\end{array}$ \\
\hline 1 група $(n=30)$ & $14,6+9,9^{*}$ & $4,5+4,6$ & $6,2 \pm 2,5^{*}$ \\
\hline II група $(n=30)$ & $20,8+12,2$ & $6,2 \pm 5,1$ & $2,8+0,9$ \\
\hline
\end{tabular}

За даними ряду авторів, зменшення об'єму хоріона та індексу васкуляризації на 70 \% І більше В ранніх термінах гестації призводить В подальшому ДО розвитку важкої плацентарної дисфункції та втрати вагітності [5-7].

ВИСНОВОК. Вивчення особливостей формування судинного компонента хоріона при невиношуванні в І триместрі гестації дозволить виявити про- вагітними. Імовірно, зменшення об'єму плідного яйця при невиношуванні обумовлене підвищеним тонусом міометрія, внаслідок якого плідне яйце зазнає підвищеного тиску ззовні.

щодо локалізації хоріона в порожнині матки нами встановлено, ЩО при загрозі невиношування він візуалізувався в ділянці внутрішнього вічка в 33,3 \% випадках, тоді як у здорових жінок в $10 \%$. можливо, передлежання ворсинчастого хоріона може вважатися несприятливим фактором для перебігу вагітності та розвитку плацентарної дисфункції.

Вивчення закономірності формування судинного компонента хоріона при загрозі переривання вагітності в 7-9 тижнів за допомогою тривимірного УЗД показало (табл. 2), що об'єм хоріона в основній групі В 1,5 раза менший В порівнянні 3 контролем. Індекс васкуляризації, який відображає вІдсотковий вмІст судинних елементів В певному об'ємі плацентарної тканини, також В 3 рази був нижчим, ніж при фізіологічній вагітності раннього терміну. Достовірної $*$ різниці В індексах кровотоку між дослідженими групами встановлено не було.

Таблиця 2. Характеристика судинного компонента хоріона при загрозі переривання вагітності

\begin{tabular}{|c|c|c|c|}
\hline $\begin{array}{c}\text { Групи } \\
\text { досліджених }\end{array}$ & $\begin{array}{c}\text { V хоріона, } \text { сM }^{3}, \\
\mathrm{M}+\mathrm{rn}\end{array}$ & $\begin{array}{c}\mathrm{VI}, \\
\mathrm{M}+\mathrm{rn}\end{array}$ & $\begin{array}{c}\mathrm{Fl}, \\
\mathrm{M}+\mathrm{rn}\end{array}$ \\
\hline I група $(\mathrm{n}=30)$ & $8,4 \pm 0,9^{*}$ & $3,9+2,1^{*}$ & $33,0+14,2$ \\
\hline II група $(\mathrm{n}=30)$ & $12,3+1,1$ & $14,5+1,1$ & $40,0+13,6$ \\
\hline
\end{tabular}

гностичні критерії розвитку первинної плацентарної дисфункції та патології вагітності В подальшому.

ПЕРСПЕКТИВИ ПОДАЛЬШИХ ДОСЛІДЖЕНЬ. Вивчення об'єму хоріона та вмісту судинних елементів В ньому В динаміці фізіологічної I патологічної вагітності В I триместрі гестації, ЩО дасть можливість сформувати групи ризику щодо подальшого патологічного перебігу вагітності.

\section{СПИСОК ЛІТЕРАТУРИ}

1. Краснопольский В. И. Возможности прогнозирования осложнений беременности при допплерометрии в I триметре гестации / В. И. Краснопольский, В. А. Туманов, Л. И. Титченко // Российский вестник акушера-гинеколога. - 2003. - № 3. - С. 5-9.

2. Милованов А. П. Внутриутробное развитие человека : руководство для врачей / А. П. Милованов, С. В. Савельев. - М. : МДВ, 2006. - 384 с.

3. Сидельникова В. М. Невынашивание беременности - современный взгляд на проблему / В. М. Сидельникова // Вестник Российской ассоциации акушер. и гинекол. - 2007. - № 2. - С. 62-64.
4. Сидорова И. С. Клинико-диагностические аспекты ФПН / И. С. Сидорова. - М. : МИА, 2005.

5. Титченко Л. И. Трехмерная реконструкция в । триместре беременности / Л. И.Титченко, М. А. Чечнева, Н. В. Жукова // Российский вестник акушерагинеколога. - 2003. - № 5. - С. 16-20.

6. Developments of three-dimensional power Doppler ultrasound imaging of fetoplacental vasculature / A. W. Welsh, K. Humphries, D. O. Cosgrove [etal.] // Ultrasound Med. Biol. - 2001. - Vol. 27 (9). - P. 1161-1170.

7. Kurjak A. Three - dimensional and power Doppler in the study of angiogenesis / A. Kurjak, S. Kupesic, T. Zoclan // Ultrasound Obstet. Gynecol. - 2001. - Vol. 18 (4). 